\title{
Strategi Guru Pendidikan Agama Islam dalam Mengimplementasikan Pendidikan Islam Multikultural di SMP Negeri 2 Mlandingan Situbondo Jawa Timur
}

Fausi

Institut KH. Abdul Chalim Mojokerto, Jawa Timur

Keywords:

PAI Teachers Strategy,

Education of Islam

Multicultural

Kata Kunci:

Strategi Guru PAI,

Pendidikan Islam

Multikultural

\section{*Correspondence \\ Address:}

fauzee4444@gmail.co

$\mathrm{m}$
Abstract: This study discusses the strategies of Islamic religious education teachers in implementing multicultural Islamic education at SMP Negeri 2 Mlandingan Situbondo, East Java, as well as supporting factors and their occupants. This study uses descriptive qualitative methods having research respondents' selection techniques using purposive sampling, in addition to data collection using observation, interview, and documentation techniques, data analysis using descriptive analysis techniques, data validity was checked by using source triangulation, as well as checking members and peer discussions. The results of this study show that: First, strategic planning, program planning, and planning within learning activities which all contain aspects of multicultural Islamic education, especially in Islamic education subjects. Second, the implementation aspect, the understanding of multicultural Islamic education is carried out in various ways and activities, such as reading the Qur'an which contains multicultural Islamic education values. Commemoration of religious holidays (commemoration of Prophet Muhammad SAW's birthday, hijriyah's new year, Ied Adha, and distribution of zakat fitrah), as well as habituation (dhuhur prayer in congregation, shaking hands, praying before starting lessons) and which contain a lot of multicultural educational value. Third, the evaluation aspect is carried out in two ways (implementation of multicultural Islamic education and learning activities). Then in the aspect of supporting and inhibiting factors in which there are 6 (six) factors found: learning objectives, learning materials, students, facilities, time allocation, and teachers.

Abstrak: Penelitian ini membahas tentang strategi guru pendidikan agama Islam dalam mengimplementasikan pendidikan Islam multikultural di SMP Negeri 2 Mlandingan Situbondo Jawa timur, serta faktor pendukung dan penghabatnya. Penelitian ini menggunakan metode kualitatif deskriptif dengan teknik pemilihan informan purposive sampling. Pengumpulan data menggunakan teknik observasi, wawancara dan dokumentasi, analisis data menggunakan analisis deskriptif, validitas data menggunakan triangulasi sumber, serta pengecekan anggota dan diskusi teman sejawat. Hasil penelitian menunjukkan: Pertama, perencanaan strategis, perencanaan program dan perencanaan kegiatan pembelajaran memuat aspek pendidikan Islam multikultural, terutama pada mata pelajaran PAI; Kedua, aspek implementasi, pemahaman pendidikan Islam multikultural dilakukan dengan berbagai cara dan kegiatan, seperti pembacaan Qur'an yang mengandung nilai pendidikan Islam Multikultural, peringatan hari besar keagamaan, serta pembiasaan sholat berjema'ah, berjabat tangan, berdoa sebelum memulai pelajaran; ketiga, evaluasi dilaksanakan pada aspek Pembelajaran dan praktek nilai multikultural. Faktor pendukung dan penghambat meliputi tujuan pembelajaran, materi pembelajaran, siswa, fasilitas, waktu dan guru. 


\section{PENDAHULUAN}

Bila bangsa ini ingin menjadi kuat, maka diperlukan adanya sikap saling menghargai, menghormati, memahami dan sikap saling menerima dari tiap individu yang beragam itu, sehingga dapat saling membantu bekarja sama dalam membangun negara menjadi lebih baik. Untuk mempunyai individuindividu yang bertanggung jawab atas dirinya sendiri dan menghormati individu lainnya diperlukan adanya pemahaman, bahwa perbedaan bukanlah menjadi satu persoalan. Yang lebih penting adalah bagaimana menjadikan perbedaan-perbedaan itu menjadi indah, dinamis dan membawa berkah. Multikulturalisme adalah proses pembudayaan. Oleh sebab itu proses pendidikan adalah proses pembudayaan, maka masyarakat multikulturalisme hanya dapat diciptakan melalui proses pendidikan. ${ }^{1}$

Pendidikan mempunyai peran penting dalam membentuk kehidupan publik, selain itu juga diyakini mampu memainkan peranan yang signifikan dalam membentuk politik dan kultural. Dengan demikian pendidikan sebagai media untuk menyiapkan dan membentuk kehidupan sosial, sehingga akan menjadi basis institusi pendidikan yang sarat akan nilai-nilai idealisme. ${ }^{2}$ Menurut para ahli sosiologi pendidikan, terdapat relasi resiprokal (timbal-balik) antara dunia pendidikan dengan kondisi sosial masyarakat. Relasi ini bermakna bahwa apa yang berlangsung dalam dunia pendidikan merupakan gambaran

1 H. A. R. Tilaar, Multikulturalisme Tantangantantangan Global Masa Depan Dalam Transformasi Pendidikan Nasional (Jakarta: PT. Grafindo, 2004), xxvii.

2 M. Agus Nuryatno, Mazhab Pendidikan Kritis Menyingkap Relasi Pengetahuan, Politik, dan Kekuasaan (Yogyakarta: Resist Book, 2008), 81. 3 Ngainun Naim \& Achmad Sauqi, Pendidikan dari kondisi yang sesungguhnya di dalam kehidupan masyarakat yang komplek. ${ }^{3}$ Dengan demikian, sekolah adalah epitome (skala kecil) dari masyarakat.

Dalam norma prosedural, kode perilaku, susunan struktural, distribusi kekuasaan, keistimewaan dan tanggung jawab, sekolah mencerminkan nilainilai cultural masyarakatnya. Kepala sekolah, Guru, administrator sekolah, dan para pembuat kebijakan (policy maker) membawa pengalaman dan perspektif kultural sendiri dan memberikan pengaruh terhadap setiap keputusan dan tindakan pendidikan, demikian pula siswa dari berbagai latar belakang etnik dan budaya tak dapat dielakkan. Berbagai sistem budaya yang berbeda ini berjumpa dalam sekolah dan ruang kelas yang pluralistik dan dapat menimbulkan konflik budaya, yang hanya dapat dimediasi dan direkonsiliasi melalui efektifitas proses instruksional yang mencerahkan, membuka batasan-batasan kultural (Cultural Boundaries) yang kaku dan tidak cair. ${ }^{4}$

Pendidikan multikultural dalam perspektif Islam, berprinsip pada demokrasi, kesetaraan, dan keadilan ini ternyata kompatibel dengan doktrindoktrin Islam dan pengalaman historis umat Islam. Adapun doktrin Islam yang mengandung prinsip demokrasi, kesetaraan, dan keadilan, antara lain, ditemukan keberadaannya dalam AlQur'an surat Al-Syura 42.5 Al-Hadid

Multikultural Konsep dan Aplikasi (Yogyakarta: Ar-Ruzz Media, 2008), 13.

4 Zakiyuddin Baidhawy, Pendidikan Agama Berwawasan Multikultural, (Jakarta: Erlangga, 2005), 31.

5 Qs. Al-Syura (42):38: "dan (bagi) orang-orang yang menerima (mematuhi) sertuan Tuhannya dan mendirikan shalat, sedang urusan mereka 
(57):25. ${ }^{6}$ dan Al-A'raf (7): 18. ${ }^{7}$ Menurut Abdul Latif Ibrahim, ketika ayat alQur'an di atas memberikan landasan moral dan etik bahwa setiap orang memiliki hak untuk memperoreh perlakuan yang adil, baik dalam soal ucap, sikap, maupun perbuatan. Perlakuan adil di sini, menurut Latif, berkaitan dengan interaksi sosial antara orang muslim satu dengan orang muslirn lainnya dan antara orang muslim dan orang non muslim. ${ }^{8}$ Perlakuan adil juga berkaitan dengan interaksi sosial antara orang etnik arab dengan orang non Arab, dan antara orang berkulit hitam dengan orang berkulit putih. ${ }^{9}$ Dengan kata lain, Islam tidak mengajarkan doktrin rasisme, yang menempatkan suatu kelompok secara superior atas kelompok yang lain karena faktor ras dan etnik.

Doktrin Islam tentang prinsip
demokrasi
kesetaraan (ar-musawah), dan keadilan (al'adl) di atas telah dipraktikkan oleh Rasulullah saw untuk mengelola keragaman kelompok dalam masyarakat di Madinah. Pada saat pertama kali memasuki kota Madinah, misalnya, Nabi saw membuat perjanjian tertulis yang populer dengan sebutan Piagam Madinah. Piagam ini menetapkan seluruh penduduk Madinah memperoleh status yang sama atau persamaan dalam kehidupan. Prinsip demokrasi, kesetaraan, dan

(diputuskan) dengan musyawarah antara mereka ; dan mereka menafkahkan sebagain dari rizeki yang Kami berikan kepada mereka 6 QS. Al-Hadid (57):25: "sesungguhnya Kami telah mengutus rasul-rasul Kami dengan membawa bukti-bukti yang nyata dan telah Kami turunkan bersama mereka al-Kitab dan neraca (keadilan) supaya manusia dapat melaksanakan keadilan ..."

7 QS. Al-A'raf (7) : 181 : "Dan diantara orangorang yang Kami ciptakan ada umat yang memberi petunjuk dengan hak, dan dengan yang keadilan terkandung dalam Piagam Madinah pada pasal 16 dan 46 sebagai berikut:

"Dan bahwa orang Yahudi yang mengikuti kami akan memperoleh hak perlindungan dan hak persamaan tanpa ada penganiayaan dan tidak ada orang yang membantu musuh mereka " (pasal 16).

"Dan bahwa Yahudi al-Aus, sekutu mereka dan diri (jiwa) mereka memperoleh hak seperti apa yang terdapat bagi mereka memperoleh hak seperti apa yang terdapat bagi pemilik sahifat ini serta memperoleh perlakukan yang baik dari pemilik sahifat ini (Pasal 46)."10

Dua pasal Piagam Madinah di atas menunjukan bahwa Nabi Muhammad saw memiliki kepedulian tinggi terhadap persoalan demokrasi, keseteraan, dan keadilan antar etnis, antar ras dan antar agama. Selain itu, dua pasal Piagam madinah juga mengandung pesan moral bahwa Nabi Muhammad SAW menolak adanya diskriminasi, hegemoni, dan dominasi dalam kehidupan di masyarakat yang majemuk. Dengan demikian, dari sudut perspektif modern, dua pasal di atas dapat menjadi inspirasi untuk membangun masyarakat multikultural. Sementara itu, dari sudut perspektif pendidikan, dua pasal tersebut dapat dijadikan sebagai dasar untuk

baik itu (pula) mereka menjalankan keadilan." 8 Lihat Abd al-Latif Ibrahim, Tasamuh al-Gharb maa al-muslimin fi al-Asr al-Hadist, (Riyad: Dari ibn al-Jawzi, 1999), 44-45

9 Abdullah al-Habsyi, Hak - hak sipil dalam Islam : Tinjauan Kritis Tekstual dan Kontekstual atas tradisi Ahlul Bait, (Jakarta : Al Huda, 2004), 23 10 Lihat J. Sayuthi Pulungan, Prinsip-prinsip Pemerintahan dalam Piagama Madinah ditinjau dari pandangan Al-Qur'an, (Jakarta, Raja Grafindo Persada, 1996), 150 
mengembangkan pendidikan multikultural.

Seperti telah disebutkan di atas, sekolah adalah epitome (skala kecil) dari masyarakat, salah satu bentuk pendidikan dalam masyarakat adalah pendidikan formal (sekolah). Sekolah inilah yang menjadi salah satu media pemahaman tentang nilai-nilai multikultural tersebut.

Oleh karena itu proses pendidikan di sekolah pun harus menanamkan nilai-nilai multikultural. Berkenaan dengan SMP Negeri 2 Mlandingan, yang merupakan salah satu sekolah di bawah naungan pemerintah kabupaten Situbondo, di dalamnya terdapat keberagaman dan sangat heterogen. Dugaan ini berdasarkan pengamatan dan wawancara awal dengan kepala sekolah, wakil kepala sekolah dan guru agama di SMP Negeri 2 Mlandingan, ${ }^{11}$ menurut informasi di SMP Negeri 2 Mlandingan ini ada berbagai macam etnis atau suku dan budaya. Etnis peserta didik dan staf pengajar tidak berasal dari satu etnis saja, ada madura dan ada jawa. Dengan adanya keberagaman dan perbedaan kultural ini rentan terjadinya perselisihan dalam interaksi di lingkungan sekolah. Namun hal ini bisa menjadi permasalahan ketika mereka tidak menerima perbedaan- perbedaan itu.

SMP Negeri 2 Mlandingan merupakan sebuah sekolah yang siswa serta gurunya meski berasal dari daerah yang berbeda-beda dengan beragam kultur dan bahkan berbeda etnis mereka bisa menjaga hubungan baik di lingkungan sekolah, walaupun secara kultural terdapat perbedaan antar warga sekolah. Hal tersebut tidak

11 Observasi dan pra wawancara awal ini dilakukan pada tanggal 3 Juni 2020

12 Pra wawancara awal bersama dengan terlepas dari peran guru PAI di sekolah dalam melaksanakan tugasnya demi terciptanya suasana multikultural dan iklim sekolah yang sehat. Contoh kasus ketika di sekolah pernah terjadi persaingan-persaingan yang dilakukan peserta didik, baik masalah akademis maupun non-kademis. Masalah tersebut tidak sampai meluas menjadi hal yang besar karena segera ditangani oleh pihak sekolah khususnya oleh guru PAI, kepala sekolah dan para guru yang lain. Selain itu juga adanya indikasi bahwa, ada peserta didik yang kurang senang ketika ada guru yang dipandang pilih kasih atau membeda-bedakan dengan sesama peserta didik. ${ }^{12}$ Berkaitan dengan masalah ini, merupakan sebuah tantangan dan pengalaman bagi guru PAI di SMP Negeri 2 Mlandingan dalam menumbuhkan semangat toleransi, kebersamaan, dan persaudaraan sehingga mampu menerapkan nilainilai multikultural di lembaga pendidikan tersebut. Dalam pelaksaannya ada 2 (dua) Persoalan yang diperhatikan (1) Bagaimana strategi guru PAI dalam mengimplementasikan pendidikan Islam Multikultural di SMP Negeri 2 Mlandingan Situbondo Jawa Timur (2) Apa saja faktor pendukung dan penghambat strategi guru PAI dalam mengimplementasikan pendidikan Islam multikultural di SMP Negeri 2 Mlandingan Situbondo Jawa Timur.

\section{METODE PENELITIAN}

Dalam penelitian ini peneliti menggunakan tehnik dan pendekatan penelitian kualitatif deskriptif dengan menggunkan teknik pemilihan informan menggunakan purposive

beberapa siswa kelas $1 \mathrm{X}$ di SMP Negeri 2 Mlandingan tanggal 3 Juni 2020 
sampling, di samping pengumpulan datanya menggunakan teknik observasi, wawancara dan dokumentasi, analisis data menggunakan teknik análisis deskriptif dengan validitas data menggunakan triangulasi sumber, pengecekan anggota dan diskusi teman sejawat.

\section{HASIL DAN PEMBAHASAN}

\section{Strategi Guru PAI dalam meng- implementasikan Pendidikan Islam Multikultural}

Strategi merupakan perencanaan, langkah, dan rangkaian untuk mencapai suatu tujuan, maka dalam pembelajaran guru harus membuat suatu rencana, langkah-langkah dalam mencapai tujuan. Strategi pembelajaran pada dasarnya adalah tindakan nyata dari guru atau praktek guru melaksanakan pengajaran melalui cara tertentu, yang dinilai lebih efektif dan lebih efisien. Dengan perkataan lain strategi pembelajaran adalah taktik yang digunakan guru dalam melaksanakan/ praktek mengajar dikelas.

Oleh karena itu, jelas bahwa strategi butuh sebuah perencanaan yang matang dan sistematis, kemudian di implentasikan dan di evaluasi sebagai kontrol untuk melihat hasil yang telah dilakukan. selanjutnya strategi guru PAI di SMPN 2 Mlandingan untuk mengimplementasikan pendidikan Islam yang multikultur harus melalui 3 tahapan; yaitu : (1) perencanaan, (2) Implementasi (proses pelaksanaan) dan (3) Evaluasi.

\section{a. Perencanaan Pendidikan Islam Multikultural}

Dalam hal ini SMP Negeri 2 Mlandingan yang notabene berbeda suku/etnis dan budaya melaksanakan pengembangan kurikukulum berwawasan Islam multikultural, terutama pada mata pelajaran PAI. Karena kurikulum merupakan pedoman awal untuk menyelenggarakan pendidikan sesuai visi dan misi, asal usul daerah, dan skill peserta didik. Dalam pengembangan kurikulum tersebut ada 3 (tiga) hal sebagai berikut: pertama, perencanaan strategis, yaitu menyusun standar kompetensi, isi, dan standar program serta strategi pelaksanaan kurikulum secara keseluruhan yang disusun oleh sekolah; Kedua, Perencanaan Program, yaitu menyusun kompetensi dasar dan materi atau pokok bahasan pada mata pelajaran Pendidikan Agama Islam yang didesain langsung oleh Guru PAI; Ketiga, Perencanaan Kegiatan Pembelajaran silabus dan RPP, disusun oleh Guru PAI dengan fokus pada penyusunan indikator pencapaian kompetensi, materi pembelajaran, dan evaluasi pembelajaran.

Sedangkan model kurikulum Pendidikan Agama Islam berbasis multikultural di SMP Negeri 2 Mlandingan berorientasi pada: Pertama, Pemahaman bahwa setiap agama adalah berbeda menurut keyakinan pemeluknya masing-masing hal ini disesuaikan dengan Visi dan misi sekolah; Kedua, Pemahaman Islam secara menyeluruh (kaffah), meliputi aspek akidah, muamalah, serta sejarah; Ketiga, pemahaman hal-hal yang sangat prinsip dalam agama, agar bersikap hati-hati dalam berinteraksi dengan pemeluk agama lain dan tetap menjunjung tinggi rasa saling menghormati perbedaan. terutama perbedaan suku/etnis dan budaya yang ada dan sudah tertanam dalam diri civitas akademika SMPN 2 Mlandingan Situbondo. 


\section{b. Implementasi Pendidikan Islam Multikultural}

Secara faktual, peserta didik SMP Negeri 2 Mlandingan memiliki keragaman, suku, ras, dan budaya. Dengan demikian pihak sekolah mengambil langkah-langkah kebijakan untuk memberikan kebebasan kepada peserta didik agar saling menghargai dan menghormati realitas yang beragam dan mampu menciptakan sikap kebersamaan. Hal ini senada dengan pendapat Abdurrahman Mas'ud yang mengatakan bahwa: Paling tidak ada empat faktor penyebab kegagalan pendidikan agama Islam. Pertama, penekanan pendidikan agama lebih pada proses transfer ilmu agama dari pada proses transformasi nilai-nilai keagamaan dan moral peserta didik. Kedua, adanya sikap bahwa pendidikan agama tidak lebih dari sekedar hiasan kurikulum belaka atau sebagai pelengkap yang dipandang sebelah mata. Ketiga, kurangnya penekanan pada nilai-nilai moral yang mendukung kerukunan beragama, seperti cinta, kasih sayang, persahabatan, suka menolong, suka damai dantoleransi. Keempat, kurangnya perhatian untuk mempelajari agama-agama lain. ${ }^{13}$

Adapun implementasi pendidikan Islam multikultural pada mata pelajaran PAI di SMPN 2 Mlandingan sebagai berikut, Pertama, Materi Islam multikultural di SMP Negeri 2 Mlandingan meliputi materi inti yaitu ; materi keimanan dan ketaqwaan, perilaku atau ahlak mulia, dan materi sikap toleransi dan materi penunjang mata pelajaran diantaranya :Latihan membaca Al-Qur'an dan sholat dhuhur berjama'ah serta pembinaan karakter.

13 Abdurrahhman Mas'ud, "Format Baru Pola Pendidikan Keagamaan para Masyarakat Multikultural dalam Perspektif SISDIKNAS", dalam Mu'tamar Ramadhan dan Hesti Herdinah
Kedua, pendidikan Islam multikultural dalam proses pembelajaran difokuskan pada dua hal diantaranya lingkungan fisik, serta kegiatan sosial dan keagamaan. Pada Lingkungan Fisik Ada dua tempat yang dipakai dalam proses pembelajaran pada mata pelajaran PAI, pertama di ruang kelas dan yang kedua di luar ruang kelas (musholla). Disamping itu nilai-nilai Islam multikultural juga ditemukan pada penggunaan metode pembelajaran yaitu metode ceramah, tanya jawab, diskusi dan praktik dengan pendekatan PAIKEM (Pembelajaran Aktif, Inovatif, Kreatif, dan Menyenangkan) sesuai karakteristik kompetensi dasar mata pelajaran PAI, sedangkan pada Kegiatan Sosial dan Keagamaan Keimanan dan Ketaqwaan terhadap Tuhan yang Maha Esa, tercermin dalam kegiatan berikut seperti: (1) Memperingati hari besar keagamaan (Tahun baru hijriyah, Maulid Nabi Muhammad SAW,dan Idul Qurban); (2) Mengembangkan dan memperdayakan kegiatan keagamaan di sekolah; (3) Mengadakan kegiatan lomba-lomba yang bernuansa keagamaan, Pembinaan budi pekerti dan akhlak mulia, (4) Kegiatan 5K (Kebersihan, Ketertiban, Keindahan, Kekeluargaan, dan Kerindangan), Pembinaan kepribadian unggul, berwawasan kebangsaan, dan bela negara.

\section{c. Evaluasi Pendidikan Islam Multikultural}

Pada aspek evaluasi pelaksanaan pendidikan multikultural, SMP Negeri 2 Mlandingan sebenarnya tidak jauh berbeda dengan sekolah-sekolah lain. Sekolah ini juga menerapkan kurikulum

(eds), Antologi Studi Agama dan Pendidikan. (Semarang: Aneka Ilmu, 2004), 74-92 
sebagaimana sekolah yang lain. Dalam hal evaluasi kurikulum, SMP Negeri 2 Mlandingan sebagaimana yang ditemukan peneliti meliputi hal-hal sebagai berikut:

Pertama, Evaluasi pendidikan Islam multikultural pada aspek pembelajaran menekankan pada pembentukan dan pembinaan budi pekerti dan akhlak mulia. Kedua, Kurikulum yang ada senantiasa dikembangkan dengan menyesuaikan pada keadaan peserta didik. Ketiga, Masukan dan saran yang diterima oleh pihak sekolah, kemudian menjadi pertimbangan terhadap evaluasi dan perbaikan materi pendidikan di sekolah. Keempat, peserta didik memahami dengan baik, pendidikan Islam multikultural khususnya yang berkaitan dengan perbedaan suku/etnik dan budaya, Kelima, Pada proses pembelajaran, penerapan pendidikan Islam multikultural nampak jelas dari berbaurnya peserta didik yang berbeda suku/etnis,ras dan budaya. Keenam, Dukungan pihak terkait seperti guru PAI, memberikan motivasi tersendiri kepada peserta didik dalam rangka mewujudkan budi pekerti yang baik dan penanaman akhlak mulia. Ketujuh, Lembar observasi bentuk daftar cek (check list) untuk evaluasi kemampuan berinteraksi dalam kegiatan siswa dan lembar evaluasi antar teman (peer assessment) terhadap kemampuan berinteraksi dalam kegiatan.

\section{Faktor Pendukung dan Penghambat Strategi Guru PAI dalam Mengimplementasikan Pendidikan Islam Multikultural}

Dalam sebuah pelaksanaan strategi pembelajaran ada 6 faktor yang dapat menjadi pengaruh terhadap terdukungnya atau terhambatnya strategi pembelajaran. dalam hal ini juga menjadi faktor pendukung dan penghambat strategi guru pendidikan agama Islam dalam mengimplementasikan pendidikan Islam multikultural, diantaranya:

\section{a. Faktor tujuan pembelajaran}

Tujuan pembelajaran merupakan titik fokus dalam proses pembelajaran untuk membentuk tingkah laku peserta didik setelah menyerap pembelajaran Islam multikultural yang dilaksanakan disekolah. Tujuan pembelajaran berfokus pada penggambaran tingkah laku peserta didik setelah proses pembelajaran selesai dilaksanakan, dimana Tingkah laku tersebut digambarkan dalam 3 aspek, yaitu pengetahuan (aspek kognitif), keterampilan (aspek psikomotorik), dan sikap (aspek afektif). Ketiganya harus bermuara pada tujuan nilai-nilai pendidikan Islam multikultural.

Pembahasan tersebut diatas sesuai dengan pendapat Tilaar bahwa: Paling tidak ada tiga tujuan dari pendidikan yang berwawasan multikultural yaitu: (1) Tujuan Atitudinal (sikap), yakni membudayakan sikap sadar, sensitive, toleran, respek terhadap identitas budaya, responsive terhadap berbagai permasalahan yang timbul dalam masyarakat; (2) Tujuan Kognitif, yakni terkait dengan pencapaian akademik, pembelajaran berbagai bahasa, memperluas pengetahuan terhadap kebudayaan yang spesifik, mampu menganalisa dan menginterpretasi tingkah laku budaya dan menyadari adanya perspektif budaya tertentu; (3) Tujuan Intruksional, yaitu menyampaikan berbagai informasi mengenai berbagai kelompok etnis secara benar di dalam teks maupun dalam pengajaran, membuat strategi tertentu dalam menghadapi masyarakat yang plural, menyiapkan alat konseptual untuk komunikasi 
antar budaya dan untuk pengembangan keterampilan, mempersiapkan teknik evaluasi dan membuka diri untuk mengklarifikasi dan penerangan mengenai nilai-nilai dan dinamika budaya. ${ }^{14}$

\section{b. Faktor materi pembelajaran}

Secara teoritis di dalam materi pembelajaran terdapat beberapa sifat materi, yaitu fakta, konsep, prinsip, masalah, prosedur (keterampilan), dan sikap (nilai). Pada hakikatnya, ilmu atau materi pelajaran memiliki karakteristik yang berbeda-beda. Menguasai materi pembelajaran Islam multikultural akan menjadi salah satu penentu berhasil atau tidaknya strategi pembelajaran yang digunakan oleh guru, terutama guru pendidikan agama Islam dalam mengimplementasikannya disekolah.

Materi pembelajaran merupakan salah satu komponen sistem pembelajaran yang memegang peranan penting dalam membantu siswa mencapai standar kompetensi dan kompetensi dasar. Dengan materi pembelajaran memungkinkan siswa dapat mempelajari suatu ko mpetensi atau kompetensi dasar secara runtut dan sistematis, sehingga secara akumulatif mampu menguasai semua kompetensi secara utuh dan terpadu. ${ }^{15}$

\section{c. Faktor Peserta didik}

Adapun Faktor siswa dalam pelaksanaan strategi pembelajaran sangatlah berpengaruh penting, dan guru harus memahami 2 (dua) aspek dari siswa; Pertama, Latar belakang siswa (pupil formative experience) meliputi jenis kelamin siswa, tempat

14 Tilaar, H.A.R. Multikulturalisme: TantanganTantangan Global Masa Depan dalam Transformasi Pendidikan Nasional. (Jakarta: Grasindo, 2004), 82

15 Siska Meitasari, Efektivitas Penggunaan Model Pembelajaran Tipe NHT dalam Meningkatkan Penguasaan Materi dan Aktivitas kelahiran, tingkat sosial ekonomi, dan dari keluarga bagaimana siswa berasal. Kedua, Sifat yang dimiliki siswa (pupil properties) meliputi kemampuan, pengetahuan dan sikap.

Faktor siswa sebagai salah satu daya dukung atau penghambat perlu memperhatikan dua aspek dari siswa itu sendiri, karena kepribadian mereka bermacam-macam ada yang pendiam, ada yang periang, ada yang suka bicara, ada yang kreatif, keras kepala, manja dan juga tidak dapat disangkal bahwa setiap siswa memiliki kemampuan atau tingkat kecerdasan yang bervariasi. Perbedaan-perbedaan semacam itu menuntut perlakuan yang berbeda pula baik dalam penempatan atau pengelompokan siswa maupun dalam perlakuan guru dalam menyesuaikan gaya belajar.

\section{d. Faktor fasilitas}

Fasilitas merupakan faktor pendukung dan penghambat dalam pelaksanaan strategi pembelajaran. Ketersediaan fasilitas merupakan faktor pendukung bagi pelaksanaan strategi pembelajaran, begitu juga sebaliknya. akan menjadi sebuah penghambat dalam strategi pembelajaran, jika fasilitas tidak tersedia.

Kelengkapan fasilitas akan membantu guru PAI dalam menyelenggarakan proses pembelajaran Islam Multikultural. Dengan demikian Fasilitas merupakan komponen penting yang dapat mempengaruhi proses pembelajaran. Karena fasilitas merupakan sarana dan prasarana. Sarana yang dimaksud disini

Belajar Siswa Pada Materi Pokok Pertumbuhan dan Perkembangan Pada Manusia (Kuasi Eksperimen Pada Siswa Kelas VIII Semester Ganjil SMP Negeri 1 Baradatu Tahun Pelajaran 2012/2013), 2013, 15 dalam http://digilib.unila.ac.id/8324/15/BAB\%202.p df 
juga yaitu segala sesuatu yang mendukung secara langsung terhadap kelancaran proses pembelajaran misalnya media pembelajaran, alat-alat pelajaran, perlengkapan sekolah dan lain-lain. Sedangkan prasarana adalah segala sesuatu yang secara tidak langsung dapat mendukung keberhasilan proses pembelajaran misalnya jalan menuju sekolah, penerangan sekolah, kamar kecil dan lain-lain.

Fasilitas dan sumber pembelajaran juga menjadi salah satu faktor yang mempengaruhi dalam menentukan strategi pembelajaran PAI. Sering kita temukan dalam proses pembelajaran di kelas bahwa pendidik sebagai sumber pembelajaran satusatunya. Padahal seharusnya peserta didik diberi kesempatan untuk berperan sebagai sumber pembelajaran dalam proses pembelajaran

\section{e. Faktor waktu}

Dalam proses pembelajaran butuh waktu, alokasi waktu perlu diatur dalam menjalankan sebuah strategi pembelajaran yang sesuai dengan tujuan pembelajaran dan menjadi faktor penting dalam pembagian waktu pembelajaran agar dapat menyusun kerangka pembelajaran, utamanya strategi pembelajaran yang baik.

Seorang guru juga harus memperhatikan alokasi waktu, hal ini sangat berakibat tidak baik kepada pola pikir siswa jika dalam proses pembelajaran tidak dialokasikan waktunya. jika terlalu sedikit, maka materi ataupun strategi pembelajarannya tidak akan tersampaikan dengan tuntas. Begitu pula jika waktunya terlalu lama, akan membuat siswa bosan dan tidak efektif dalam pelaksanaan strategi pembelajaran. Tentunya juga akan mengganggu terhadap proses pembelajaran. Waktu juga merupakan salah satu faktor penting dalam strategi pembelajaran yang dapat berindikasi kepada perilaku siswa untuk menghargai waktu dalam kehidupan sehari-hari. Adapun alokasi waktu pada mapel PAI adalah 3 jam pelajaran, begitu pula yang berlaku di SMP Negeri 2 Mlandingan.

\section{f. Faktor guru}

Seorang guru adalah pengendali dari proses pembelajaran. gurulah yang mempunyai strategi dalam sebuah proses pembelajaran, dan guru juga sebagai panutan peserta didik dalam pengimplementasian pendidikan Islam multikultur disekolah. Seorang guru PAI tidak hanya mendidik, tapi juga membimbing peserta didik agar berperilaku sesuai dengan ajaran Islam yang multikultur.

Guru merupakan komponen yang sangat menentukan dalam implementasi suatu strategi pembelajaran. Tanpa guru, bagaimanapun bagus dan idealnya suatu strategi, maka strategi itu tidak mungkin dapat diaplikasikan. Layaknya seorang prajurit di medan pertempuran. Keberhasilan penerapan strategi berperang untuk menghancurkan musuh akan sangat bergantung kepada kualitas prajurit itu sendiri. Demikian juga dengan guru, keberhasilan implementasi suatu strategi pembelajaran akan tergantung pada kepiawaian guru dalam menggunakan metode, teknik, dan taktik pembelajaran. Diyakini, setiap guru akan memiliki pengalaman, pengetahuan, kemampuan, gaya, dan bahkan pandangan yang berbeda dalam mengajar. Guru yang menganggap mengajar hanya sebatas menyampaikan materi pelajaran, akan berbeda dengan guru yang menganggap mengajar 
adalah suatu proses pemberian bantuan kepada peserta didik. Masing-masing perbedaan tersebut dapat memengaruhi baik dalam penyusunan strategi atau implementasi pembelajaran.

\section{SIMPULAN}

Berdasar hasil penelitian tersebut dapat disimpulkan, bahwa strategi guru PAI di SMPN 2 Mlandingan untuk mengimplementasikan pendidikan Islam yang multikultur harus melalui tahapan; yaitu: Pertama, pada aspek perencanaan, SMP Negeri 2 Mlandingan menerapkan beberapa kegiatan, meliputi perencanaan strategis (visimisi, asal-usul dan kemampuan peserta didik), perencanaan program (melibatkan tim pengembang kurikulum) dan perencanaan kegiatan pembelajaran (kegiatan, materi, metode dan alat evaluasi). Kedua, Produk yang dihasilkan dari perencanaan program di SMP Negeri 2 Mlandingan adalah standart kompetensi, kompetensi dasar, SKL dan RPP yang kesemuanya memuat aspek pendidikan Islam multikultural terutama pada mata pelajaran PAI.

Implementasi Pendidikan Islam multikultural di SMP Negeri 2 Mlandingan adalah: Pertama, Materi pendidikan Islam multikultural merupakan materi inti, yaitu materi keimanan dan ketaqwaan, perilaku atau akhlak mulia, materi sikap toleransi dan Materi penunjang mata pelajaran diantaranya: Latihan membaca AlQur'an, Sholat dhuhur berjema'ah dan pembinaan karakter; Kedua, pendidikan Islam multikultural dalam proses pembelajaran difokuskan pada dua hal diantaranya lingkungan fisik dan kegiatan sosial dan keagamaan.

Evaluasi pelaksanaan pendidikan Islam multikultural di SMPN 2
Mlanndingan, Pertama, evaluasi pendidikan Islam multikultural pada aspek pembentukan dan pembinaan budi pekerti atau akhlak mulia; Kedua, kurikulum yang ada senantiasa dikembangkan dengan menyesuaikan pada keadaan peserta didik; Ketiga, masukan dan saran yang diterima oleh pihak sekolah menjadi pertimbangan dalam kegiatan evaluasi di sekolah; Keempat, Peserta didik memahami dengan baik pendidikan Islam multikultural khususnya yang berkaitan dengan perbedaan suku/etnis dan budaya; Kelima, Pada proses pembelajaran, penerapan pendidikan Islam multikultural nampak jelas dari berbaurnya peserta didik yang berbeda suku/etnis dan budaya; Keenam, Dukungan pihak terkait, memberikan motivasi tersendiri kepada peserta didik dalam rangka mewujudkan budi pekerti yang baik dan penanaman akhlak mulia; Ketujuh, lembar observasi bentuk daftar cek (check list) untuk evaluasi kemampuan berinteraksi dalam kegiatan siswa; Kedelapan, lembar evaluasi antar teman (peer assessment) terhadap kemampuan berinteraksi dalam kegiatan.

Ada 6 (enam) faktor yang dapat menjadi pengaruh terhadap terdukung atau terhambatnya strategi pembelajaran yaitu: tujuan pembelajaran, materi pembelajaran, siswa, fasilitas, waktu dan guru.

\section{REFERENSI}

Baidhawy, Zakiyuddin, Pendidikan Agama Berwawasan Multikultural, (Jakarta: Erlangga, 2005)

Habsyi, Abdullah, Hak - hak sipil dalam Islam: Tinjauan Kritis Tekstual dan Kontekstual atas tradisi Ahlul Bait, (Jakarta : Al Huda, 2004) 
Ibrahim, Abd al-Latif, Tasamuh al-Gharb maa al-muslimin fi al-Asr al-Hadist, (Riyad: Dari ibn al-Jawzi, 1999)

Mas'ud, Abdurrahhman, "Format Baru Pola Pendidikan Keagamaan para Masyarakat Multikultural dalam Perspektif SISDIKNAS", dalam Mu'tamar Ramadhan dan Hesti Herdinah (eds), Antologi Studi Agama dan Pendidikan. (Semarang: Aneka Ilmu, 2004)

Meitasari, Siska, Efektivitas Penggunaan Model Pembelajaran Tipe NHT dalam Meningkatkan Penguasaan Materi dan Aktivitas Belajar Siswa Pada Materi Pokok Pertumbuhan dan Perkembangan Pada Manusia (Kuasi Eksperimen Pada Siswa Kelas VIII Semester Ganjil SMP Negeri 1 Baradatu Tahun Pelajaran 2012/2013), 2013, 15 dalam http://digilib.unila.ac.id/8324/15/ BAB\%202.pdf

Naim, Ngainun \& Achmad Sauqi, Pendidikan Multikultural Konsep dan Aplikasi (Yogyakarta: Ar-Ruzz Media, 2008)

Nuryatno, M. Agus, Mazhab Pendidikan Kritis Menyingkap Relasi Pengetahuan, Politik, dan Kekuasaan (Yogyakarta: Resist Book, 2008)

Pulungan, J. Sayuthi, Prinsip-prinsip Pemerintahan dalam Piagama Madinah ditinjau dari pandangan Al-Qur'an, (Jakarta, Raja Grafindo Persada, 1996)

Tilaar, H. A. R., Multikulturalisme Tantangan-tantangan Global Masa Depan Dalam Transformasi Pendidikan Nasional (Jakarta: PT. Grafindo, 2004) 